1. Crossings: Journal of Migration \& Culture

2. Volume 9 Number 1

3. (c) 2018 Intellect Ltd Article. English language. doi: 10.1386/cjmc.9.1.91_1

4.

5.

6.

\title{
Mediating identity:
} The West African diaspora, conflict and communication

\section{ABSTRACT}

Migration raises many existential problems, not least, questions of identity. Over time, migrants settle and form a diaspora in a new land but does dislocation from their geographical 'home' inevitably subvert their sense of self? Can representation through the diasporic media mitigate this loss? The African Union considers the diaspora the sixth region of Africa and the news media helps foster amongst exiles an 'imagined diaspora' (Anderson), connecting them to their country of origin. In the social media age, this 'diaspora of the Internet' (Tettey) can be seen at work, often acting as a mirror for division and disharmony in the country of origin. Taking a case study approach of three countries in West Africa and interpreting conflict in its broadest senses, this article seeks to examine the ways in which the news-related media of the West African diaspora has influenced understandings of identity.

\section{Introduction}

Being African is an increasingly complex identity. As someone who has been told she is too black to be British, and too British to be African, I am strongly against the notion that identity can be policed by some external standard. 
The journalist and author, Afua Hirsch, has good reason to consider notions of 1 . identity and belonging. She was born in Britain to a black Ghanaian mother 2 . and white British father, whose own father was a Jewish exile from Nazi 3. Germany. Those seeking to pigeon-hole might describe her as an 'Afropolitan', 4. an African born in the diaspora or an African who identifies with both their 5 . African and European heritage. (There are various academic contestations of 6 . the term 'Afropolitan', which are beyond the remit of this article.)

Another commentator who straddled two cultures, the American-born 8. James Baldwin, who found his unique voice in Paris during the 1950s, was 9. far less nuanced in his analysis of racial identity: 'All you are ever told about 10 . being black in this country (the United States) is that it is a terrible thing to be' 11 . (Baldwin and Troupe 2014).

The reason for beginning this article with quotes about identity from 13 . two writers of different generations is to point up the transformation of the 14 . diasporic public sphere in the intervening decades. Baldwin's undoubted 15. influence on American identity politics was shaped by his writing and public 16 . speaking, his views sharpened in his formative years by physical distance from 17 . his country of origin. In the twenty-first century, Hirsch has a far greater range 18 . of communicative tools at her disposal as well as the advantage of occupying 19 . a liminal deterritorialized space. When she lived and worked in Ghana for a 20. number of years she was still able to engage regularly, both in British identity 21 . debates and issues around African migration and culture, by blogging. It is the 22 . influence of this public space on notions of identity, which is the subject of 23 . this article.

Diaspora media acts as a kind of hinge between two continents and 25 . two heritages and can be highly influential especially in its representation 26 . of conflict and upheaval. Yet, at a time when its impact is potentially more 27 . far-reaching than ever, the role of this media has been under-researched. 28. Oyeleye (2017: 25) makes the point that, as an umbrella term, 'media of the 29. diaspora' elides importance differences between the 'professionalism' and 30 . ethics of journalism and the more free-flowing social media ecology, which 31. has opened up new spaces of communication. Tettey describes the latter as 32 . the 'diaspora of the Internet' (2009) and this article is a response to the'need 33. to problematize the liminality of diasporic engagement with politics and 34 . identity in order to be able to analyze the relationships between home and 35 . diaspora ...' (Oyeleye 2017: 29).

This inquiry focuses on West Africa because of the geographical proxim- 37. ity of the countries which provide case studies and the similar historical/social 38 . divides in two of them and because of the author's own research experiences in 39. that region. Whereas there has been extensive research into the influence of the 40 . diaspora on conflict and upheaval in the Horn of Africa, especially Eritrea and 41. Somalia (Chama 2017), comparatively little has been done on the other side 42 . of the continent. Through a series of interviews, supplemented by a reading of 43 . secondary sources, it aims for a qualitative assessment of diasporic commen- 44 . tary on inter alia, party political and ethno-regional divides in Sierra Leone, 45. Liberia's enduring legacies from the nineteenth century, the image of Nigeria 46. abroad and coverage of a war crimes trial and other human rights issues. 47 .

\section{African diaspora, identity and conflict}


1. resolution and peace building through access to donor agencies (Lyons 2004).

2. On the other hand, Brinkerhoff sees the potential for diaspora communities

3. to 'raise money to support continuing warfare, promote public opinion and

4. interventions in support of their cause' (Brinkerhoff 2006: 27). While Anderson

5. describes as 'long distance nationalism' the temptation of the disaffected

6. diaspora member 'to play identity politics' in the conflicts of his homeland

7. (Anderson 1992: 13).

8. Georgiou argues that it is time to move beyond such 'utopian/dystopian'

9. distinctions (2013: 81), but this contested ground offers a useful frame in

10. which to analyse the relationship of the media of the African diaspora to iden-

11. tity formation. A helpful starting point in this quest is Palmer's definition of

12. the modern African diaspora as consisting of:

13.

14.

15.

16.

17.

18.

19.

20.

21.

... the millions of peoples of African descent living in various societies who are united by a past based significantly, but not exclusively, on 'racial' oppression and the struggles against it; and who [...] share an emotional bond with one another and with their ancestral continent; and who also, regardless of their location, face broadly similar problems in constructing and realizing themselves.

(Palmer 1998: 3)

However, this definition does not include that element of diaspora consciousness captured by Benedict Anderson's 'imagined community'. In other words, the element coming from within the perceptions of the community itself. It is imagined (original emphasis) because the members of even the smallest nation will never know most of their fellow members, meet them, or even hear of them, yet in the minds of each lives the image of their communion' (Anderson 1983: 49). It is an image fostered and magnified by media representation, in Oyeleye's words: 'helping to sustain diaspora formations and to enhance a sense of diaspora consciousness' (Oyeleye 2017: 29).

In his study of democracy in Africa, Nic Cheeseman writes that, although such pressures as elections inevitably aggravate tensions between communities, "the politics of belonging was not equally pronounced across the continent $[\ldots]$ they $(s i c)$ were most pronounced in more diverse countries where governments had actively favoured some ethnic groups and discriminated against others' (Cheeseman 2015: 157).

Although generally sound, this formula does not hold for all African states. Rwanda is one of the least diverse countries in Africa, with a unitary language (Kinyarwanda) and only three tribal groups, Hutu, Tutsi and Twa. Here, the construction of a mythic diaspora by Hutu supremacists and supported by government, was a necessary component of the decades of propaganda, which led ultimately to the genocide of 1994 . The story that the Tutsi were a Nilotic people who migrated to central Africa and imposed a despotism over the indigenous Hutu and Twa was woven into the fabric of prejudice, which animated Radio Rwanda and the infamous private station, Radio Télévision Libre Des Milles Collines (Prunier 1995; Melvern 2000). Some might see an irony in the fact that it was the military force of a genuine diaspora, Rwandan exiles living in Uganda and Tanzania, which overthrew the Hutu regime and ended the genocide.

The unashamed partisanship and low ethical standards of much Africanbased media, whether on the side of government or opposition, one tribal group or another, are accepted as the facts of life in many parts of the 
continent. In the case of Sierra Leone for example, the post-war Truth and 1 .

Reconciliation Commission observed that: 2.

Some newspapers are in danger of becoming little more than scandal -4 sheets, relying on proactive and, at times, dishonest headlines in order 5 . to promote sales.

(Truth and Reconciliation Commission Report 2004: 80) 7.

So, the research questions underpinning this article are these: when it comes 9 . to the lens trained on Africa by the media of the diaspora, does distance lend 10 . objectivity, even impartiality? Or is the freedom afforded by a home, however 11 . temporary, in another country or on another continent, 'conferring the privi- 12. lege of being able to intervene in certain domestic debates without fear of 13 . retribution' (Wai 2012: 243), regarded as a safe space in which to fight identity 14. battles with even more partiality?

\section{Methodology}

study, taking an inductive approa pretation of secondary pretation of secondary texts. The interviewees are media representatives whose 21. country of origin is either Liberia, Sierra Leone or Nigeria and whose work 22. has, in different ways, been shaped by the conflicts in that West African region, 23. whether conflict defined as war or as internal political upheaval and ethnic 24 . contestation. They were asked to reflect principally on the issue of identity, 25 . interpreted flexibly in a number of different ways: attachment to and under- 26 . standing of tribal/ethnic affiliation, political/party grouping and the interests 27 . of the nation and/or Africa as a continent. Some of the ground covered also 28. embraces the various strands of relationship forged in the host country which, 29. in the social media age, create what has been called 'the connected migrant' 30 . (Diminescu 2008). 31.

The interview transcripts and the texts - news dispatches, opinion pieces, 32 . blogs and reports - were subjected to thematic analysis, drawing patterns of 33 . meaning from the discursive construction of media, conflict and identity, and 34 . seeking to elicit common themes in the three case studies. This is a small-scale 35 . inquiry done in a short time-scale, with the interviewees chosen only on the 36 . basis of freely available published material, so it makes no large claims about 37 . being representative of diaspora intervention in the three countries. As stated 38 . earlier, this is relatively an un-researched terrain so more extensive investiga- 39 . tion is called for.

\section{Data analysis}

Dr Zubairu Wai (quoted above) is a Sierra Leonean scholar who migrated 45 . to Canada. His birth country was lacerated by a decade-long civil war in the 46 . 1990s and during that period, diaspora journalists and campaigners saw it as 47 . their responsibility to publicize in foreign policy circles the issues dividing their 48 . homeland. "The media and internet became part of the diasporic communi- 49 . cative spaces and avenues for networking. These spaces helped the diaspora 50. articulate certain views and opinions regarding the conflict, while allowing 51. them to keep in touch with events back home' (Wai 2012: 234). As an example, 52. 
1. the Internet discussion forum, Leonenet, founded in 1991/2 at the start of

2. the violence, helped demystify the origins and character of the rebel force,

3. the Revolutionary United Front (RUF) 'at a time when information about the

4. conflict and the insurgents was limited and misleading at best' (Wai 2012: 34).

5. The online newsletter, Focus on Sierra Leone, published by Ambrose Ganda

6. in the United Kingdom, where the largest expatriate Sierra Leonean community

7. lived, not only carried regular updated news and opinion on the conflict but

8. became a valuable conduit for advocacy and lobbying for a negotiated settle-

9. ment after Ganda established contacts with the RUF. And following the 1997

10. coup, which overthrew the SLPP government and brought in the short-lived

11. Armed Forces Revolutionary Council, two exiled Sierra Leoneans, who found

12. refuge in neighbouring Guinea, set up a radio station, FM 98.1, as a diasporic

13. mouthpiece for the ousted president, Ahmed Tejan Kabbah (Wai 2012: 235).

14. Wai believes that focusing on whether diasporas play a positive or nega-

15. tive role is a 'false binary that is both problematic and self-limiting' (Wai 2012:

16. 209), but others, both inside and outside the media, take a different view. And

17. some appear conflicted about their role. Sanpha Sesay, who blogs under the

18. sobriquet, 'The Texas Chief' from Dallas, swapped a position as press attaché to

19. the Secretary of State for Development and Economic Planning in Freetown

20. for that of assistant editor-in-chief of the Salone Monitor. He left a devastated

21. country behind when he sought asylum in the United States in 1999 and

22. joined some 3000 Sierra Leoneans in the Dallas Metro area:

23.

24.

25.

26.

27.

28.

29.

30.

31.

32.

33.

34.

35.

36.

37.

38.

39.

40.

41.

42.

43.

44.

45.

46.

47.

48.

49.

50.

51.

52.

Journalism in the diaspora is about coming together. I see my main goal as promoting political and social change in Sierra Leone. The country is so divided into supporters of the two political parties [the governing All People's Congress and the opposition Sierra Leone People's Party] that its national identity is seriously compromised. I want to change this polarisation because it brings no economic value to Sierra Leone.

(Sesay 2017)

As an illustration of his self-proclaimed mission, Sesay posted this blog in 2014 after learning that some opponents of the government were refusing to play an active role during the Ebola crisis, accusing the president of siphoning off funds intended for the health service:

For us in the Diaspora, we have the duty to educate our people about the consequences of this Ebola virus and avoid politicizing it. It is not a disease brought by APC or SLPP; neither had it come from north, south, west nor east region, as the president [Ernest Bai Koroma] spelt out clearly ... Help! Help! It is your duty and responsibility. God bless Sierra Leone.

(Sesay 2014)

However, Sesay's call for a non-partisan diaspora response to Sierra Leone's problems is rather undermined by his admission that he is a member of the APC:

I was neutral, unaligned when I was living and working in Sierra Leone but in 2006, a friend here in the US influenced me to join the APC. Most prominent Sierra Leone journalists, whether at home or in the diaspora, are associated with one of the parties. That's the way it's always been.

(Sesay 2017) 
Sanpha Sesay's apparently contradictory views offer a revealing insight into 1 . what might be called Sierra Leone's 'identity crisis'. The term, 'ethno-regional 2. divide', was used in the Introduction to this article and it requires some eluci- 3. dation here. Like Liberia, modern (i.e. post-eighteenth century) Sierra Leone 4. was shaped by the influx of former or freed slaves from the Americas and West 5 . Indian colonies. This cohort, known as Krios, settled in and around Freetown 6. and henceforth, occupied an elevated social status, in comparison with the indig- 7 . enous tribal population. According to the judge and media scholar, Abou Bhakarr 8 . Muhammed Binneh-Kamara, as late as the 1960s it was almost impossible for a 9 . non-Krio to be appointed to a judicial position even though many amongst the 10 . country's largest single ethnic group, the Mende, were known to have acquired a 11. good level of education and vocational experience (Binneh-Kamara 2018). 12.

In many respects, Sierra Leone remains a country fractured along 13. ethnic and regional lines and its domestic media reflects these divisions 14. (see Silverman and Binneh-Kamara 2016). As an example, the Sierra Leone 15. Telegraph published an unashamedly partisan account of a political rally held 16 . in London addressed by a putative presidential candidate for the Sierra Leone 17. Peoples Party, Brigadier Julius Maada Bio, in December 2017. The language in 18. the report was a world away from the journalistic ideal of impartiality: 19.

He was passionate, confident and assuring as he addressed hundreds of 21. Sierra Leoneans at the prestigious Royal Regency Hall in London. [...] 22. With his usual humility after delivering his statement, Rtd.Brigadier Bio 23. went table after table thanking the guests for gracing the fundraising 24 . dinner as a sign of confidence in his leadership [...]The show of love 25 . and affection towards Bio continues to demonstrate his huge popularity 26 . at home and abroad.

(Thomas 2017) 28.

And for good measure, his wife, Mrs Fatima Bio, is described as 'beautiful and 30. elegant'. The byline on the report is that of Abdul Rashid Thomas, editor and 31 . proprietor of the newspaper, yet it is hard to discern the input of a professional 32. journalist in his copy. Perhaps the clue lies in a declaration at the foot of the 33 . page, 'Article written by the SLPP Information, Media and Communications 34 . Committee'.

In Sierra Leone, political allegiance and ethnicity are deeply intertwined. 36. Of the two dominant tribal groups, the Mende of the south and east have 37. traditionally supported the SLPP, while the Temne of the north vote for the 38 . APC. Preferment in many professions, including the media, is often depend- 39. ent on which party is in power. Such a lack of fluidity in affiliation is often 40 . mirrored in diaspora groups and it is understandable that some scholars argue 41 . that 'diasporas often frame conflicts in ways that are uncompromising and 42 . categorical' (Lyons 2004: 21). This appears to be true of many of the communi- 43 . cative spaces occupied by the Sierra Leonean diaspora: 44 .

When I go on Facebook or Twitter, I am acutely aware of the divisive and often hateful language when discussing politics used by people, whether they live in Toronto or London or Freetown. I am a Temne from the north of my country and my name immediately gives away my ethnic and regional origin. So, a Mende social media user will pick up on that and treat me with hostility. And there is no way of regulating this kind of discourse.

(Binneh-Kamara 2018) 
1. Since the turn of the millennium, Western media has engaged in a protracted

2. internal debate about its portrayal of African states such as Sierra Leone. The

3. Economist headlined its opinion piece of May 2000, while the war was still

4. raging, 'Hopeless Africa' (11 May 2000). By the second decade, the same jour-

5. nal was writing about 'A hopeful continent' (August 2013). But the Economist's

6. gaze is an exterior one. The same examination of progress or regression goes

7. on in the media of the diaspora and tends to validate Tettey's assertion that

8. within the mediascape of the Internet, Africans are actively engaging in politi-

9. cal and policy discourse in their country of origin (Tettey 2009). Sanpha Sesay,

10. blogging from Texas, is a good exemplar of this interventionism, even at the

11. cost of portraying his country in a negative light:

12.

24.

What is specifically necessary for us to do in our various destinations in the diaspora is very critical. In the first place, we have to use our influence by informing big economic powers and donor agencies about the daunting problems that rage in our country. It is our responsibility to cry to the world about problems such as electricity and water supply so that people will come to our aid. The Western world respects journalists, therefore our news reporting could create a positive impact if we keep reporting about our difficulties that need external help.

(Sesay 2013)

\section{Liberia}

If Sierra Leone's fractured identity is reflected back by the diaspora media, then the same is true of Liberia, whose history is entwined with that of its neighbour.

The diasporic writer, Emmanuel Dolo, argues that the enduring fissures in Liberian society explain the 'absence of a cohesive national identity' and that 'ethnic bigotry and class discrimination' have caused a 'national identity crisis' (Dolo 2007: xx). So, what are these fissures?

The support given by Liberia's Charles Taylor to the RUF rebels who attacked Sierra Leone in 1991, was a catalyst for the vicious war of the following decade. As stated earlier, both states grew from the reintroduction of freed slaves from North America into their territories in the nineteenth century. In Liberia's case, too, this influx and its relationship to the indigenous population has had social, economic and political consequences, which are still being felt in the twenty-first century.

The so-called Americo-Liberians (sometimes known as Congo Town Liberians) formed a dominant diasporic elite, whose influence has been so potent that, until the election of George Weah in 2017, only one president, Samuel Doe, an ethnic Krahn, had come from outside this community. Indeed, the coup instigated by Doe in 1980 has been interpreted as a revolt of the politically marginalized against the hegemony of the advantaged AmericoLiberians. In the wake of the political turmoil of the 1980s, many Liberians sought exile abroad, fostering: 'The idea that the Liberian middle class sat out the war in the United States, and that its return will shape Liberia's future ...' (Steinberg 2011: 41).

The diaspora media in the United States did little to dispel this notion, and in the first free elections after the war's end, in 2005, many reports pointed out the disparity between the qualifications of Ellen Johnson-Sirleaf, a former 
1. It is worth noting that accusations that some of the exiles financed the military campaign which triggered the start of the civil war, were investigated by Liberia's Truth and Reconciliation Commission. The TRC took evidence in the United States and recommended the lustration of Johnson-Sirleaf
World Bank economist, and her ill-educated challenger, George Weah. ${ }^{1} 1$. However, the election of Africa's first democratically elected female president 2 . was not, in itself, a panacea for Liberia's ills. Steinberg's research into one 3. of the largest Liberian communities in the United States, on Staten Island, 4. New York, illustrates how the diaspora of a country at war becomes a kind of 5 . mirror of the conflict. As the war was ending in 2003 and the political actors 6 . in Liberia were competing for power and influence, a struggle broke out for 7 . control of the elected body representing Staten Island's Liberians. Reports in 8 . the Staten Island Advance, fuelled by partisan commentary from the various 9 . factions, attest to the bitterness of the rupture:

It is no stretch to suggest that what was being enacted here was a proxy or a metaphor; that a community abroad was playing out its fears about the situation at home.[...] It is tempting to conclude that the Staten Island protagonists were stand-in figures, and that the stage on which they fought was erected by collective anxiety about the uncertain peace back home.

The largest Liberian diaspora population in the United States is in Minnesota 20. and it took an active part in the 2017 election that Weah won. According to 21. community activist, Abdullah Kiatamba:

Minnesota is not just an observer or a sideline cheering squad. People are involved here as much as people on the ground in Liberia. Minnesota is shaping and influencing things. People are literally living in two worlds around this election.

(Covington 2017) 28.

Much of this involvement came through social media platforms, described 30 . as a 'gamechanger' by broadcaster, Al-Hussein Fadiga, whose online station 31. Radio Africa attracted thousands of new listeners throughout the campaign. 32. 'You cannot successfully win elections in Liberia without huge support from 33 . the diaspora community', according to Wynfred Russell, who runs a non- 34 . profit organization. However, that also means that familiar tropes of Liberian 35 . practice are just as prevalent, with the remittance payment used as leverage. 36. 'People will say openly, "Look, if you don't support my candidate, you can rest 37. assured I'm not going to send you money for Christmas". Proverbially, you 38. cannot bite the hand that feeds you' (Covington 2017). 39.

But the thematic evidence informing this article does not run in one direc- 40 . tion only. The African Union's description of the diaspora as 'the sixth region 41. of Africa' (the others being North, South, East, West and Central Africa) is not 42. merely an acknowledgment of the benefit brought to the continent by the 43 . remittance economy. It also recognizes the ability of the diaspora to harness 44 . citizen engagement in a myriad other ways. Like Sierra Leone, Liberia suffered 45. horribly from the regional Ebola outbreak of 2014 and 2015, as already thread- 46. bare health services buckled under the strain. The initial response of the World 47. Health Organisation was inadequate and research has shown that the dias- 48 . poras of both countries provided a measure of medical relief in response to 49 . media-led publicity. Reports in the Liberian publication, Frontpage Africa (2014 50. and 2015), cited by Robtel Neajai Pailey, describe shipments of relief materi- 51 . als, paid for and organized by diasporan Liberians in the United States and 52 . 
1. Europe. She argues that this opened up a 'third humanitarian domain' (Horst

2. et al. 2016) sending the same kind of assistance that the diaspora provided 3. during the armed conflicts of the 1990s.

4. But she goes further, positing that the relief effort was an assertion of 5. identity, in that it not only eased the burden on the government in Monrovia 6. but'also enabled Liberian diasporas to practise citizenship from afar, thereby 7. expanding the spatial contours of the state and public authority "outside" 8. (author's quotation marks) of its geographic ambit' (Pailey 2017: 665).

9.

10.

11.

12.

13.

14.

15.

16.

17.

18.

19.

20.

21.

22.

23.

24.

25.

26.

27.

28.

29.

30.

31.

32.

33.

34.

35.

36.

37.

38.

39.

40.

41.

42.

43.

44.

45.

46.

47.

48.

49.

50.

51.

52.

A similar 'expansion' took place during the years 2007-10, in a different context, when a small cohort of journalists from Liberia and Sierra Leone provided daily radio reports from The Hague on the war crimes trial of the former Liberian president, Charles Taylor. ${ }^{2}$ The journalists were natives of the countries they were broadcasting to but' over the lifetime of the project became a temporary diaspora in the heart of Europe' (Silverman 2017: vii). One of the Liberian reporting team was Joseph Cheeseman, who lived through the Liberian conflict, which ended only in 2003. He reflects on the psychological difference brought by geographical separation from the homeland:

I felt I had a kind of dual identity when I was living and working in The Hague. Obviously I was from Africa, but I simply saw myself as part of an international press corps, as a journalist among equals, without any perception of being an African subject to the kind of ethno-political pressures we experience at home. Objectivity was always my watchword. However, at some points of the trial, when witnesses alleged that Taylor and others had indulged in cannibalism, I was greatly embarrassed, especially when a lady from the Democratic Republic of Congo, sitting near me in the press gallery, asked if there were no animals in Liberia, that we (Liberians) had to resort to eating humans.

(Cheeseman 2017)

The 'pressures at home' are another indication of the divide between the 'Americo-Liberian' elite, of which Cheeseman is a member (one of his ancestors, Joseph James Cheeseman, was the twelfth president of Liberia, serving between 1892 and 1896) and the indigenous majority. He accepts that the historical/cultural connection is a significant part of his own identity, which he does not seek to deny. By contrast, the celebrated Liberian-born journalist, Helene Cooper, who works for The New York Times, found it hard openly to confront her identity for many years: 'I travelled all over the world, writing about wars and conflict and all sorts of things - everything except Liberia which I basically embedded in my head' (Cooper 2008).

\section{Nigeria}

As the case studies of Sierra Leone and Liberia have demonstrated, the deterritorialized space occupied by the media of the diaspora has undoubtedly had an impact on perceptions of African identity. It is possibly less true of West Africa than East Africa, but social media platforms, such as Facebook, have allowed the diaspora to intervene in 'real time' in political contestation at home. However, as the UK-based African media academic, Dr George Ogola, observes:

...while digital technologies, such as social media, have now been widely adopted in Africa, millions remain unconnected to the Internet. This
2. The project was run by the charitable arm of the BBC, BBC Media Action, under the umbrella title 'Communicating Justice'. The author was the consultant/mentor. 
means that these new platforms are inaccessible to the masses. Traditional media - particularly radio - therefore remain an important platform for public engagement. At election times, these kinds of legacy media formats are critical in enabling the public to make informed choices.

(Ogola 2017) 5

1.

2.

3.

4.

6.

With the pace of technological change becoming ever faster, television prob- 7 . ably counts as 'legacy media' for some, especially the young. But its influence 8 . should not be discounted. The Nigerian diaspora channel, BEN Television 9. (BEN standing for Bright Entertainment Network), based in London, had an 10. image of itself as an avatar of 'Afropolitanism' when it began broadcasting to 11 . audiences both in the host country and Nigeria in 2003. Nigerians make up 12. the largest African diaspora in the United Kingdom. As the channel's own 13. prospectus put it:

BEN television is a black-oriented, urban, diverse and cosmopolitan family channel introducing new, cultured programmes to European taste [...]. It also includes a range of cultured programming to empower, transform and challenge the conventional perception of Africa and Africans.

(BEN Television www.bentelevision.com 2007)

Nigerian media scholar, Abiodun Adeniyi, suggests that the prospectus held the promise that:

a new element in transnational communication is coming because the programmes are no longer going to be entirely African; neither are they going to be reproducing white, liberal Eurocentrism. [...]Through a consumption of BEN TV programmes therefore, the migrant may acquire a new worldview, one that is not entirely African.

$$
29 .
$$

(Adeniyi 2016: 54) 30.

31.

This vision speaks to diaspora media being a 'lateral' connecting factor 32 . for many second-generation diaspora Africans, linking them, not so much 33 . with people from the ancestral homeland, but with other black citizens of 34 . the country in which they live and the concerns that animate them, such as 35 . the 'Black Lives Matter' movement. But BEN TV's founder and chair, Alistair 36. Soyode, explains that early aspiration has had to give way to financial reality: 37 .

When we started, we wanted to reach the black community in the 39 United Kingdom as well as the African diaspora. But we do not have 40. the money to put on ambitious original programming or hire our own 41. reporters. And in any case, black British viewers would compare us with 42 . mainstream British television and find us wanting so we have had to 43 . fall back on unpaid 'community correspondents' and 'free' content from 44 . Africa's largest network, NTA (Nigerian Television Authority), which 45. runs 100 stations all over Africa.

(Soyode 2017) 47.

With more consistency than Sanpha Sesay in Texas, Soyode admits that 49 . his guiding philosophy is to present images of positivity about his home- 50 . land. In Soyode's case, to counter the stereotype of Nigerians as 'lawless and 51. constantly perpetrating fraudulent schemes'. BEN TV offers a fairly traditional 52. 
1. format, with studio discussion (one weekly programme, dealing with migra-

2. tion and resettlement issues, is called 'In Diaspora' and connects viewers/

3. listeners in Nigeria with a panel in London), regular segments of Christian

4. evangelism, paid for by different ministries, and news from NTA, delivered in

5. the style familiar to sub-Saharan audiences, that is, a fairly unrelenting diet of

6. poorly-edited reports on the policy announcements of politicians addressing

7. conferences. As Adeniyi comments,'stories are official and have a government

8. leaning' (Adeniyi 2016: 54).

9. Soyode acknowledges that viewers see BEN Television as a 'Nigerian chan-

10. nel' but argues that its longevity has earned it a credibility in addressing issues of

11. concern to second-generation viewers, such as deaths in police or prison custody

12. and diversity, or the lack of it, in British institutions. Despite financial constraints,

13. some 40 per cent of its live programmes deal with British domestic matters and

14. senior police officers and politicians, including the mayor of London, have partic-

15. ipated in studio-based interviews and discussions. The hybrid identity of the

16. station is mirrored by Soyode's assessment of his own status:

17.

I see myself as a hyphenated British-Nigerian, comfortable in both locations. I imagine I will go back to Nigeria to live at some point, because the country needs its best professionals, to repair its image. I would like to enter politics, and if truth be told, my ambition is to run for president in 2019. By contrast, my two children have made their lives in the United Kingdom. My son is studying PPE (Philosophy, Politics and Economics) at Oxford and my daughter works for the National Health Service. They have both been to Nigeria and know about their heritage but they see themselves as British.

(Soyode 2017)

\section{Diaspora activism, migration and identity}

BEN Television's mediated course between two cultural outlooks is, of course, a world away from the brand of activism practised by transnationalist 'advocacy' media, which has made its mark on Nigerian affairs, first during the dictatorship of Sani Abacha in the 1990s and, more latterly in the twenty-first century, by exposing social, economic and political conflict and the growth of terrorism. What Shola Olabode calls the 'exploitation of guerrilla or underground activism using electronic media, especially radio'(Olabode 2016: 131) did not deter the Abacha regime from committing human rights abuses, such as the execution of the writer/environmental campaigner, Ken Saro-Wiwa, but it may have helped pave the way for a return to democracy.

The more recent upsurge in citizen journalism, exploiting the 'heterogeneous nature of the tools of the new media' (Olabode 2016: 146) has lent a truly global dimension to campaigns such as the 'Bring Back Our Girls' (BBOG) movement, formed after the kidnap of hundreds of young women from Chibok in north-eastern Nigeria in April 2014. That the majority of the three million or so tweets, using the hashtag \#BBOG, emanated from the United States may not be unconnected with the fact that one of the most influential diaspora citizen media websites, SaharaReporters.com is based in New York city.

Citizen activism, allowing global audiences to view unfolding crises and conflicts in real time, has undoubtedly helped shrink the world of conflict and

52. transform conceptions of identity. As Olabode points out, 
At rallies and demonstrations in big cities across Nigeria, activists were seen collecting both audio and visual documentation of protests published on SaharaReporters.com, their own personal Facebook pages and Twitter, and pictures, also published on Flickr.

1. 2. 3. 4.

(Olabode:140) 5. 6.

There is, of course, another side to this social media phenomenon, and that is 7 . the extraordinary seductive power of the imagery to draw those experiencing 8 . political upheaval, war or straightforward poverty in Africa towards the prom- 9 . ise of a better life in Europe. If people in Nigeria, Chad, Mali or Libya believe, 10. or are told, that their identity no longer has to be confined to a bounded 11 . national space but can be recast in a global context, the pressure to migrate 12 . becomes irresistible.

Western (and indeed world) mainstream media has reported on the flow 14 . of peoples northwards through Africa and across the Mediterranean from a 15 . number of perspectives: as a humanitarian catastrophe, a potential immigra- 16 . tion problem for Western nations or a troubling source of terrorism. But the 17. Nigerian diaspora magazine, The African Courier, published in Germany since 18. 1998, has opted for a different approach. In August 2017, it announced an infor- 19. mation campaign under the rubric, 'Know the Facts', to warn of the dangers 20. and challenges of irregular migration. The magazine has partnered with 21. the African-German Information Center and the Migration Enlightenment 22. Project in Nigeria to work with media, civil society and government agencies 23 . to dissuade people from taking illegal routes to Europe.

It is an example of diaspora media neither acting as a mouthpiece for the 25 . government 'at home' nor adopting an oppositional stance but taking what 26 . might be called a social responsibility approach, giving 'a realistic picture of 27 . the situation of irregular migrants in Europe while also encouraging youths 28 . to look at positive alternatives to emigration available in Nigeria' (The African 29. Courier 2017). Whether any would-be migrants have consulted The African 30. Courier before embarking on their perilous journey towards Europe is, of 31. course, another matter. 32. 33.

\section{Conclusion}

This article has sought to problematize the multifarious roles played by West 36 . African diaspora media in addressing conflict in its broadest sense, not merely 37 . armed hostilities but political rivalries emanating from the 'homeland' and the 38 . challenges faced by those forced to leave their country of origin, or who leave 39 . by choice, to adapt to unfamiliar identity're-formulations'. The thematic anal- 40 . ysis has shown that it is a mutable process, which defies simple categorization: 41.

In effect migrants are straddling two or several socio-cultural spaces, -42. which, in turn, leads them to form hybrid identities in an ongoing 44 complex process of cross-fertilization, of shifting balances of power, 45 . within the self, and of fluctuating relationships with various communities. 46.

(Diminescu and Loveluck 2014: 24) 47.

48.

An examination of the diaspora media of both Sierra Leone and Liberia has 49 . shown that political and 'ethno-regional' differences that undermine each 50 . country's sense of unity are reflected and highlighted by those based abroad. 51 . In Nigeria's case, the global impact of campaigns, such as 'Bring Back Our 52. 
1. Girls', illustrates Tettey's 'diaspora of the Internet' in action. But like Sierra

2. Leone and Liberia, albeit on a far larger canvas, Nigeria's geographical, ethnic

3. and political divisions are as likely to be magnified by diaspora media inter-

4. vention as healed by it.

5. The interviews indicate that, as the world shrinks through new media affor-

6. dances, many diasporic occupants of the deterritorialized space are comfortable

7. with a 'hyphenated' identity, having a foot in both camps as it were. Sanpha

8. Sesay has lived and worked in Texas for nearly twenty years and acquired

9. American citizenship in 2010. Does he see himself as an African American?:

10.

11.

12.

13.

14.

15.

16.

17.

18.

19.

20.

21. guishes us from those black people born in the United States. Unfortunately, on official forms, there is no box you can tick which identifies you as 'Sierra Leonean American'. But as a 50-year-old, I identify with Africa in a way that young Sierra Leoneans living here do not. Many do not want to go there because of all the negative images they see on the media.

Understanding the dynamic relationship between diaspora media, conflict and identity involves an epistemological quest and many questions. Can we find any empirical measurements to assess changed identities over time in response both to relocation and media representation? How do we discover what role media has played in the mass movement of peoples from the African continent to Europe as distinct from the filtering back of experiences of other people from the same village or town? How do we judge at what point migrants become a diaspora?

One thing that can be said with some degree of confidence is that the African diaspora is now populating the online sphere in ever greater numbers, using Twitter and Facebook to influence the global debate about international development. It may not yet be true that the diaspora, through its media, is having the impact on elections and political change in Africa that it is having on development projects and advocacy, but that day may not be too far away.

\section{REFERENCES}

Adeniyi, A. (2016), 'The Media of Nigerian diaspora in Britain: A study of priorities and preferences', New Media and Mass Communication, 48:1, pp. $50-58$.

African Courier (2017), 'Nigerian diaspora to launch campaign for safe migration in lagos', www.theafricancourier.de/migration/nigerian-diasporato-launch-campaign-for-safe-,migration-in-lagos/. Accessed 29 October 2017.

Anderson, B. (1983), Imagined Communities: Reflections on the Origins and Spread of Nationalism, London: Verso.

_ (1992), 'The new world disorder', New Left Review, I/193, May-June, https://newleftreview.org/I/193/benedict-anderson-the-new-world-disorder. Accessed 12 November 2017.

Baldwin, J. and Troupe, Q. (2014), James Baldwin: The Last Interview: And Other Conversations, Brooklyn, NY: Melville House Publishing.

BEN Television Prospectus (2007), www.bentelevision.com. Accessed 14 October 2017. 
Bercovitch, J. (2007), 'A neglected relationship: Diasporas and conflict resolu- 1. tion', in H. Smith and P. Stares (eds), Diasporas in Conflict: Peacemakers or 2. Peace Wreckers, Tokyo: UNU Press, pp. 17-38.

Binneh-Kamara, Abou Bhakarr M. (2018), in person interview, London, 14. February.

Brazil, J. and Mannur, A. (2003), 'Nation, migration and globalization: Points 6 . of contestation and diaspora studies', in J. Brazil and A. Mannur (eds), 7. Theorizing Diaspora: A Reader, Malden, MA: Blackwell, pp. 1-22. 8.

Brinkerhoff, J. M. (2006), 'Digital diasporas and conflict prevention: The case of 9. Somalinet.com', Review of International Studies, 32:1, pp. 25-47. 10.

Chama, B. (2017), 'Diaspora media role in conflict and peace building from the 11. perspectives of Somali diaspora in Canada', in O. Ogunyemi (ed.), Media, 12. Diaspora and Conflict, Cham: Springer, pp. 53-68. 13.

Cheeseman, J. (2017), interviewed by e-mail, Monrovia, 28 July. 14.

Cheeseman, N. (2015), Democracy in Africa: Successes, Failures and the Struggle 15. for Political Reform, Cambridge: Cambridge University Press. 16.

Cooper, H. (2008), The House at Sugar Beach: In Search of a Lost African 17. Childhood, New York: Simon \& Schuster. 18.

Covington, H. (2017), 'Minnesotans play key role in landmark liberian election', 19. Star Tribune, 26 December, https://www.startribune.com/minnesotans- 20. play-key-role-in-landmark-liberian-election/466621893/\#/1. Accessed 221. February 2018.

Diminescu, D. (2008), 'The connected migrant: An epistemological manifesto', 23. Social Science Information, 47:4, pp. 565-79. 24.

Diminescu, D. and Loveluck, B. (2014), 'Traces of dispersion: Online media 25. and diaspora identities', Crossings: Journal of Migration and Culture, 5:1, pp. 26. 29-39. 27.

Dolo, E. T. (2007), Ethnic Tensions in Liberia's National Identity Crisis: Problems 28. and Possibilities', Cherry Hill, NJ: Africana Homestead Legacy Publishers. 29.

Georgiou, M. (2013), 'Diaspora in the digital Era: Minorities and media repre- 30. sentation', Journal on Ethnopolitics and Minority Issues in Europe, 12:4, 31. pp. 80-99. 32.

Gilroy, P. (1993), The Black Atlantic: Modernity and Double Consciousness, 33. London:Verso. 34.

Hall, S. (1990), 'Cultural identity and diaspora', in J. Rutherford (ed.), Identity: 35. Community, Culture, Difference, London: Lawrence and Wishart. 36.

Hirsch, A. (2012), 'Our parents left Africa- now we are coming home', The 37. Guardian, 26 August, www.theguardian.com/world/2012/aug/26/ghana- 38. returnees-afua-hirsch-africa. Accessed 24 July 2017.

Horst, C., Lubkemann, S. and Pailey, R. N. (2016), 'The invisibility of a third 40. humanitarian domain', in Z. Sezgin and D. Dijkzeul (eds), The New 41. Humanitarians in International Practice: Emerging Actors and Contested 42. Principles, London: Routledge, pp. 213-31.

Kony (2012), 'Invisible children', YouTube, https://www.youtube.com/ 44. watch?v=w99AntesKLSE. Accessed 4 October 2017.

Krzy囚anowski, M. and Wodak, R. (2007), 'Multiple identities, migration and 46. belonging: Voices of migrants', in C. Caldas-Coulthard and R. Iedema 47. (eds), Identity Troubles, London: Palgrave Macmillan, pp. 95-119. 48.

La Barbera, M. C. (ed.) (2015), Identity and Migration in Europe: Multidisciplinary 49. Perspectives, Cham, Heidelberg, NY, Dordrecht and London: Springer. 50.

Lyons, T. (2004), 'Emerging diasporas to promote conflict resolution: 51. Transforming hawks into doves', Working Paper Presented at Institute for 52. 
1.

2.

3.

4.

5.

6.

7.

8.

9.

10.

11.

12.

13.

14.

15.

16.

17.

18.

19.

20.

21.

22.

23.

24.

25.

26.

27.

28.

29.

30.

31.

32.

33.

34.

35.

36.

37.

38.

39.

40.

41.

42.

43.

44.

45.

46.

47.

48.

49.

50.

51.

52.
Global Conflict and Cooperation, Washington Policy Seminar, Fairfax, VA: George Mason University.

Melvern, L. (2000), A People Betrayed: The Role of the West in Rwanda's Genocide London: Zed Books.

Naficy, H. (1993), 'From broadcasting to narrowcasting: Middle Eastern diaspora in Los Angeles', Middle East Reports, 180, pp. 31-34, https://www. scholars.northwestern.edu/.../from-broadcasting-to-narrowcastingmiddle-eastern-diaspora-in-los-angeles. Accessed 5 December 2017.

Ogola, G. (2017), 'Why the role of the media is so important to free and fair elections in Africa', The Conversation, 16 May, https://www.theconversation.com/why-the-role-of-the-media-is-so-important-to-free-and-fairelections-in-africa-77568. Accessed 27 July 2017.

Olabode, S. (2016), 'Veterans of diaspora activism: An overview of ICT use amongst Nigerian migrant networks', in A. Karatzgiami, D. Nguyen and E. Serafinelli (eds), The Digital Transformation of the Public Sphere: Conflict, Migration, Crisis, London: Palgrave Macmillan.

Oyeleye, A. (2017), 'Diaspora journalism and conflicts in transnational media circuits', in O. Ogunyemi (ed.), Media, Diaspora and Conflict, Cham: Palgrave Macmillan, pp. 19-36.

Pailey, R. N. (2017), 'Liberia, ebola and the pitfalls of state-building: Reimagining domestic and diaspora public authority', African Affairs, 116:465, pp. 648-70.

Palmer, C. (1998), 'Defining and studying the modern African diaspora', Proceedings of The American Historical Association, September, Seattle, WA. Cited in Perspectives on History, the News Magazine of the American Historical Association, https://www.historians.org/publications-and-directories/perspectives-on-history-september 1998/defining-and-studying-the-modernafrican-diaspora. Accessed 4 November 2017.

Prunier, G. (1995), The Rwanda Crisis: History of a Genocide, London: C. Hurst.

Sesay, S. (2013) 'Sierra Leone Diaspora Journalists: What are our challenges?', Sierra Express, www.sierraexpressmedia.com/?p=64224. Accessed 10 August 2017.

Sesay, S. (2014), 'Diasporans should support President Koroma in the nation's lock-down instead of romanticizing and politicizing the issue', www.salonemonitor.net/diasporans-should-support-president-koroma-in-thenations-lock-down-instead-of-romanticizing-and-politicizing-the-issue. Accessed 24 July 2017.

- (2017), telephone interview, Dallas, 25 July.

Silverman, J. andBinneh-Kamara, A. (2016), 'Newspaper coverage of a Sierra Leone war crimes trial: "A continuation of conflict by other means", African Journalism Studies, 37:2, pp. 56-76.

Silverman, J. (2017), Foreword to Media, Diaspora and Conflict (ed. O. Ogunyemi), Cham: Springer, pp. v-xi.

Soyode, A. (2017), in person interview, London, 18 August.

Steinberg, J. (2011), 'A truth commission goes abroad: Liberian transitional justice in New York', African Affairs, 110:438, pp. 35-53.

Tettey, W. J. (2009), 'Transnationalism, the African Diaspora and the deterritorialized politics of the internet', in O. F. Mudhai, F. Tettey and F. Banda (eds), African Media and the Digital Public Sphere, New York: Palgrave Macmillan.

Thomas, A. R. (2017), 'It will not be business as usual - Bio assures diaspora', Sierra Leone Telegraph, 13 December, https://www.sierraleonetelegraph. 
com/it-will-not-be-business-as-usual-bio-assures-diaspora/. Accessed 311. January 2018.

2.

Truth and Reconciliation Commission Report (2004), Witness to Truth: Report of 3. the Sierra Leone Truth and Reconcilation Commission Vol II, Freetown: Sierra 4. Leone Truth Commission.

Wai, Z. (2012), 'Conflict and peacebuilding in Sierra Leone: The role of the 6 Sierra Leone diasporas', in T. Zack-Williams (ed.), When the State Fails: 7. Studies on Intervention in the Sierra Leone Civil War, London: Pluto Press, 8 pp. 203-46.

\section{SUGGESTED CITATION}

Silverman, J. (2018), 'Mediating identity: The West African diaspora, conflict and communication', Crossings: Journal of Migration $\mathcal{E}$ Culture, 9:1, pp. 91-106, doi: 10.1386/cjmc.9.1.91_1

\section{CONTRIBUTOR DETAILS}

Jon Silverman is Professor of Media and Criminal Justice at the University of Bedfordshire and co-director of the Centre for International Media Analysis, Research and Consultancy (CIMARC). He is a former BBC Home Affairs Correspondent, 1989-2002 and before that, he was BBC Europe Reporter, based in Paris, 1987-89. He is an acknowledged authority on international and post-conflict justice, having covered the trials of Slobodan Milosevic and Charles Taylor in The Hague and reported from the ICTR in Arusha. His current research interest is the relationship between Africa and the International Criminal Court.

Contact: Media and Criminal Justice, the University of Bedfordshire, Luton Campus, Park Square Luton, Bedfordshire LU1 3JU, UK.

E-mail: jon.silverman@beds.ac.uk

Jon Silverman has asserted his right under the Copyright, Designs and Patents Act, 1988, to be identified as the author of this work in the format that was submitted to Intellect Ltd.

$$
\text { . }
$$

